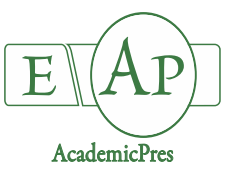

Jimborean MA et al. (2021)

Notulae Botanicae Horti Agrobotanici Cluj-Napoca

Volume 49, Issue 1, Article number 12001

DOI: $10.15835 /$ nbha49112001

Research Article

\title{
Aloe vera gel microcapsules and essential oils of thyme and oregano incorporated in spreadable goat cheese: impact on its microbiological, physicochemical, and sensory characteristics during storage
}

\author{
Mirela A. JIMBOREAN ${ }^{1}$, Andrei BORŞA ${ }^{1 *}$, Delia MICHIU ${ }^{1}$, \\ Ancuța M. ROTAR ${ }^{1}$, Cristina A. SEMENIUC ${ }^{1}$, Carmen R. POP ${ }^{1}$, \\ Liana C. SALANT, $\breve{A}^{1}$, Dorin T, TBULCĂ ${ }^{1}$, Valentin A. BÂLTEANU² \\ ${ }^{1}$ University of Agricultural Sciences and Veterinary Medicine, Faculty of Food Science and Technology, 3-5 Mănăştur Street, 400372, \\ ClujNapoca,Romania; mirela.jimborean@usamvcluj.ro; andrei.borsa@usamvcluj.ro (*corresponding author); \\ delia.michiu@usamvcluj.ro; anca.rotar@usamvcluj.ro; cristina.semeniuc@usamvcluj.ro; carmen-rodica.pop@usamvcluj.ro; \\ liana.salanta@usamvcluj.ro;dorin.tibulca@usamvcluj.ro \\ ${ }^{2}$ University of Agricultural Sciences and Veterinary Medicine, Institute of Life Sciences, 3-5 Mănăştur Street, 400372, ClujNapoca, \\ Romania; lzga.usamvcj@yahoo.com
}

\begin{abstract}
The aim of this study was to develop a new assortment of high-quality cream cheese, with a high amount of biologically active compounds, namely a spreadable cheese from goat milk with addition of Aloe vera microcapsules and essential oils of thyme and oregano. The research was focused on the testing and optimization of an appropriate manufacturing recipe for this new product. Two assortments were made: one with Aloe vera microcapsules and thyme essential oil and the other one with Aloe vera microcapsules and oregano essential oil. For each assortment two different concentrations of Aloe vera and essential oils were tested. The obtained products were analysed for organoleptic, physico-chemical (fat, protein, total dry matter, sodium chloride and acidity) and microbiological parameters. In terms of consumer preferences, the cream cheese with 3\% microcapsules of Aloe veragel and $0.018 \%$ thyme essential oil was the most appreciated in terms of commercial aspect, consistency, and taste. We concluded that the addition of Aloe vera microcapsules improves the sensory characteristics and leads to an increase nutritional value of the finished product. Also, the addition of essential oils (thyme and oregano) ensured a stable quality during storage.
\end{abstract}

Keywords: Aloe vera; essential oils; goat milk; spreadable cheese

\section{Introduction}

Essential oils (EO) are extracted from aromatic plants containing a variety of natural, biologically active components with antimicrobial and antioxidant properties (Amatiste et al., 2014; Hamedi et al., 2014; Yousefi et al., 2017, Khorshidian et al., 2018). Antimicrobial properties of essential oils against various microorganisms (L. monocytogenes, E. coli O157:H7, Aspergillus ochraceus ZMPBF 318, Penicillium spp.) have been reported in various studies (Kotzekidou et al., 2008; Yahyazadeh et al., 2008; Čvek et al., 2010; Jeong et al., 2014).

Received: 18 Jul 2020. Received in revised form: 09 Feb 2021. Accepted: 17 Feb 2021. Published online: 24 Feb 2021.

From Volume 49, Issue 1, 2021, Notulae Botanicae Horti Agrobotanici Cluj-Napoca journal will use article numbers in place of the traditional method of continuous pagination through the volume. The journal will continue to appear quarterly, as before, with four annual numbers. 
The oregano and thyme essential oils have significant antibacterial effects, due to the presence of their phenolic compounds, like carvacrol and thymol (Sakkas and Papadopoulou, 2017). In a study released by Burt and Reinders (2003), including four essential oils (oregano, thyme, bay and clove bud) the oregano and thyme oils showed the greatest antibacterial effect against Escherichia coli $\mathrm{O} 157: \mathrm{H} 7$. Various studies related to the antioxidant property of oregano essential oil, showed that it has strong antioxidant activity due to its high thymol and carvacrol content (McKay and Blumberg, 2006).

Thyme essential oil is one of the ten more important essential oils due to its proven antimicrobial, antimycotic, and antioxidant effects. Many studies have shown that thymol and carvacrol, its main constituents, are responsible for these properties. According to regulation (EC) no. 1334/2008 thyme essential oil is on the list of essential oils generally recognized as safe for ingestion.

Aloe vera is known as a perennial herb belonging to the Liliaceous family. It contains a large variety of nutrients and bioactive compounds, such as flavonoids, terpenoids, (Boudreau and Beland, 2006; Harlev et al., 2012) fatty acids, mono-and polysaccharides (pectins and hemicelluloses), tannins and sterols. It also contains a variety of enzymes, minerals (calcium, chromium, copper, iron, magnesium, manganese, potassium, phosphorus, sodium, and zinc) and vitamins (A, C, E, $\beta$-carotene, B1, B2, B3, B6, choline, B12 and folic acid) (Sahu et al., 2013; Rodrigues et al., 2018; Marzanna et al., 2019). Aloe vera is used in the food industry as a functional ingredient (Kazhal and Samira, 2015).

Microencapsulation may be defined as a packaging technology used for separating and storing materials in microscopic capsules, for later release under controlled conditions. The material that provides protection and controlled release of the bioactive compound is called coating material. In general, these matrices are natural or synthetic polymers (Cock and Castillo, 2013).

Goat milk has high nutritional properties and lower allergenic effect as compared with cow's milk, especially in non-sensitized children, which led to an increased interest in goat's milk as a functional food (Albenzio and Santillo, 2011; Hassan, 2014). Spreadable cream cheeses are fresh cheeses produced by coagulating milk, cream or whey with acid, a mixture of acid and rennet, or a combination of acid and heat (Brčina et al., 2017). Fresh cheeses are characterized as slightly acid, soft, homogeneous products that are white in colour and smooth-textured (Frau et al., 2014).

This study aimed to evaluate the effect of essential oils (i.e. thyme and oregano) and microcapsules with Aloe vera incorporation in a spreadable goat cheese product. This would enhance its nutritional value and functional properties by increasing its contents in bioactive compounds and will improve its quality and organoleptic properties.

\section{Materials and Methods}

\section{Materials}

Three successive cream cheese trials were carried out. Goat's milk was obtained from a local farm. The composition of the goat milk used was determined with an Ekomilk M apparatus (model Milkana KAM98-2A Bulteh $2000 \mathrm{Ltd}$, Stara Zagora, Bulgaria) and the mean values $( \pm)$ of three replicates for all batches were as follows: $3.85 \pm 0.07 \%$ fat, $3.78 \pm 0.02 \%$ total protein, and $8.75 \pm 0.05 \%$ non-fat dry matter. Titratable acidity was recorded as Thörner degrees $\left(\mathrm{T}^{\circ}\right)$ according to the Thörner method $\left(16.5 \pm 1 \mathrm{~T}^{\circ}\right)$, and $\mathrm{pH}$ was measured with a $\mathrm{pH}$ meter (HI 99161, Hanna Instruments, Limena, Italia) (6.71 \pm 0.02$)$. Dry plant material of two commercial plants (thyme and oregano) was used in this study to obtain essential oils. Starter cultures, including the mesophilic strains Lactococcus lactis subsp. lactis and Lactococcus lactis subsp. cremoris (Lyofast MO 142), were used. Powder animal rennet was obtained from Chr-Hansen's Laboratories (Copenhagen, Denmark). Using species-specific primers, a PCR assay was performed to certify the presence of goat milk and to detect possible undeclared cow milk addition into the bulk milk used for cheese production experiments. 


\section{Preparation of microcapsules with Aloe vera gel}

The matrix encapsulation or microencapsulation was accomplished using a laminar flow through a nozzle and an additional vibration of the nozzles or liquid (Cock and Castillo, 2013). To obtain the gel from Aloe vera leaves, they were quickly processed in order to avoid oxidation.

The Aloe vera gel was obtained by removing the shell, followed by a thermal treatment $\left(72{ }^{\circ} \mathrm{C}\right.$ for 12 sec.). Finally, the gel was chopped and homogenized. For the chemical determinations, extraction of the compounds with methanol was performed.

Microencapsulation was proposed as a successful strategy to improve the Aloe verastabilization, to make easier their handling during cream cheese processing and to ensure its bioavailability when they are used as dairy food bioactive compounds. Thus, another objective of this study was to encapsulate bioactive compounds contained in Aloe vera gel in order to obtain microcapsules usable as natural food additives.

\section{Extraction of thyme and oregano essential oils}

For the flavouring process of the cream cheese, thyme and oregano essential oils were isolated by hydro distillation, using a Clevenger type apparatus. Fifty grams of dried and minced leaves were weighed and added into a distillation flask together with $750 \mathrm{ml}$ of distilled water. The distillation process was performed during three hours. The yield was calculated as millilitres of essential oils per $100 \mathrm{~g}$ dry plant material (thyme or oregano). The obtained essential oils were dried using anhydrous sodium sulphate and stored in sealed vials at 6-8 ${ }^{\circ} \mathrm{C}$ until analysis.

\section{PCR analysis of raw goat's milk}

To identify possible undeclared addition of cow milk into goat bulk milk used for cheese production experiments, PCR assays were performed on samples collected from bulk milk under sterile conditions and transported at $4{ }^{\circ} \mathrm{C}$. For the recovery of the somatic cells required for DNA extraction, the milk samples were centrifuged at $3000 \mathrm{~g}$ for 10 minutes. DNA extraction from the cell pellet was performed with the DNesay Blood \& Tissue kit (Qiagen), according the manufacturer instructions. Milk somatic cells recovered from the samples were digested in $90 \mu \mathrm{l}$ of ATL solution and $10 \mu \mathrm{l}$ of proteinase $\mathrm{K}$, by incubation at $56^{\circ} \mathrm{C}$. Subsequently, $200 \mu \mathrm{l}$ of AL solution and $200 \mu \mathrm{l}$ of absolute alcohol were added to each tube. The lysate was transferred to the purification columns and centrifuged at $8000 \mathrm{rpm}$ for $1 \mathrm{~min}$. The columns were subsequently washed with AW 1 and AW2 solutions respectively. After centrifugation the DNA from the column filter was eluted in 50 $\mu \mathrm{l}$ of AE solution. DNA concentration and purity were spectrophotometrically evaluated.

To certify the presence of goat milk and an eventual undeclared cow milk addition into the bulk milk used as raw material we amplified two different size fragments from goat and cow mitochondrial DNA (cytochrome B gene).

PCR amplification was performed with a commercial kit (2X Green Master Mix, Fermentas) in $25 \mu \mathrm{l}$ reactions, containing: $12.5 \mu \mathrm{l}-2 \mathrm{X}$ reaction mixture (Taq polymerase, buffer, $\mathrm{MgCl}_{2}$ and $\mathrm{dNTP}$ ), $6.5 \mu \mathrm{l}$ sterile water, $2 \mu \mathrm{l}$ of common-sense primer specific for cytochrome B of both species and $1 \mu \mathrm{l}$ of each antisense primer specific for goat or cow. PCR amplification was performed in a thermocycler, under the following conditions: predenaturation $-95^{\circ} \mathrm{C}$ for 3 minutes 1 cycle, followed by 35 cycles at $94^{\circ} \mathrm{C}-1$ minute, $58^{\circ} \mathrm{C}-1$ minute, 72 ${ }^{\circ} \mathrm{C}$ - 1 minute.

To differentiate the presumptive amplification products obtained in the amplification reactions, the samples were migrated in 2\% concentration agarose gel, in 1X TBE buffer and 1X Gel Red Nucleic Acid Stain $\mathrm{Gel}$, at $75 \mathrm{~V}$ for one hour. The gel image was analysed using a UV transilluminator system. 


\section{Cream cheese manufacturing}

Three fresh cheese making trials were carried out during three successive weeks. In each trial, cheese was made in one vat. Goat's milk, obtained from a local farm, was pasteurized at $63-65^{\circ} \mathrm{C}$ for $20-30 \mathrm{~min}$. After pasteurization, the milk was cooled at $30^{\circ} \mathrm{C}$ and each milk vat was inoculated with starter culture containing about $1 \mathrm{UC} / 100 \mathrm{l}$ at the rate of $1 \%\left(3.5 \times 10^{6} \mathrm{cfu} / \mathrm{g}\right)$. After inoculation $20 \mathrm{~g} / 100 \mathrm{~L}$ of $\mathrm{CaCl}_{2}$ was added. Milk was fermented in a thermostatically controlled incubator for 1 hour at $31^{\circ} \mathrm{C}$. When $\mathrm{pH}$ reached $\leq 6.5(6.46)$, commercial rennet was added under stirring conditions in all vats. The mixtures were incubated at $25-28^{\circ} \mathrm{C}$ for about 12 hours. The curd was set in cheese-cloths and was pressed in a ripen chamber for draining at 16-18 ${ }^{\circ} \mathrm{C}$. After drainage, the curd was cooled to $10^{\circ} \mathrm{C}$.

Cream cheese with Aloe vera gel microcapsules and essential oils was made by blending and cooling at $10{ }^{\circ} \mathrm{C}$. During this procedure the cream cheese $(90 \%)$ was salted $(0.4 \% \mathrm{w} / \mathrm{w})$ and mixed with sour cream $(20 \%$ fat), $10 \%$ proportion. Two concentration of Aloe vera microcapsules ( $7 \%$ and $3 \%$ ) mixed with thyme/oregano essential oil in ratios of $0.0072 \%$ and $0.018 \%$ were used. Then, cream cheese samples were packaged in plastic cups $(250 \mathrm{~g})$ and stored in the refrigerator at $2-6^{\circ} \mathrm{C}$ for 21 days until analysis.

The control cream cheese $(\mathrm{M})$ was produced without essential oils and Aloe vera addition. The samples were coded as follows: P1C1-7\% Aloe vera microcapsules and $0.0072 \%$ thyme essential oil, P2C2-3\% Aloe vera microcapsules and $0.018 \%$ thyme essential oil, P1O1-7\% Aloe vera microcapsules and $0.0072 \%$ oregano essential oil, P2O2-3\% Aloe vera microcapsules and $0.018 \%$ oregano essential oil.

\section{Physicochemical and microbiological analysis}

Physicochemical analysis was performed using cream cheese (two samples from each cheese making trial). The methods specified in the following standards were used to determine the fat, protein, total dry matter, and sodium chloride content of the spreadable cheeses: SR ISO 3433:2009, SR EN ISO 8968-1:2014, SR EN ISO 5534:2004, SR EN ISO 5943:2007 and SR ISO 1740:2008.

The antibacterial activity of essential oils was tested on the following bacteria: Staphylococcus aureus ATCC 25923, Escherichia coli ATCC 25922 and Salmonella enteritidis ATCC 13076. The objective was to identify the minimum inhibitory concentration (MIC) and the minimum bactericidal concentration (MBC) in accordance with the National Committee for Clinical Laboratory Standards (NCCLS, 1997). The minimum inhibitory concentration (MIC) was determined by using 96 -well microtiter plates.

The microbiological determinations of the cream cheeses were performed using the following standard methods: SR ISO 16649-2: 2007 Microbiology of food and feed - Horizontal method for the enumeration of positive Escherichia coli beta-glucuronidase. Part 2: Colony enumeration technique at $44^{\circ} \mathrm{C}$ using 5-bromo4-chloro-3-indolyl beta-D-glucuronate; ISO 6881-1: 1999 Microbiology of food and animal feeding stuffs Horizontal method for the enumeration of coagulase-positive staphylococci (Staphylococcus aureus and other species) - Part 1: Technique using Baird-Parker agar medium.

\section{Sensory evaluation}

A fifty-member sensory panel (aged 21-50 years, women, and men) evaluated one cream cheese of each type at the end of the manufacturing process. The cream cheeses were evaluated for appearance (creamy white), colour (white colour such as cream - degree of whiteness, low-yellow colour), consistency (Low-hard/Higheasy to spread on a cracker, creamy feeling of fullness in the mouth) and taste (fresh sourness-reminding of yoghurt). A five-point hedonic scale was used for appearance, colour, consistency, smell, and taste, ranging from 0 (poor) to 5 (very good).

Data analyses

Data analysis was carried out using Minitab statistical software (version 16.1.0;LEAD Technologies, Inc., Charlotte, NC, USA) by one-way ANOVA with Tukey's post-hoc test, at a 95\% confidence level ( $\mathrm{p}<$ 
0.05). Statistical significance of the effects was interpreted as follows: $p \geq 0.05^{\mathrm{NS}}$, not significant; $p<0.01^{* *}$, very significant; $p<0.001^{* * *}$, extremely significant.

\section{Results and Discussion}

PCR analysis of raw goat's milk

A reference cow DNA sample was used to differentiate goat milk from cow milk (Figure 1, sample R1). In this case, a specific 274 bp fragment was obtained, which denotes the presence of mitochondrial cow DNA. In the case of DNA samples extracted and amplified from goat milk used in the preparation of the product, the presence of a single amplification product of $157 \mathrm{bp}$, specific for goat mitochondrial DNA (Figure 1, samples P1 and P2) was detected.

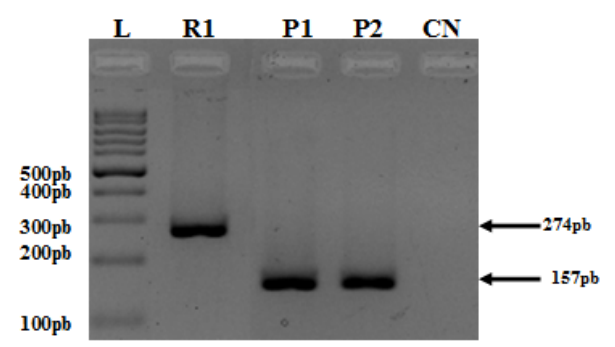

Figure 1. Specific amplification products of the cytochrome B gene from goat's and cow's milk: L-ladder 100bp; R1- cow DNA reference sample, 274 bp PCR product; P1 and P2 - DNA samples amplified from goat milk used in the preparation of the product, $157 \mathrm{bp}$ PCR product; $\mathrm{CN}$-negative control.

\section{Aloe vera gel characterization}

In order to characterize the Aloe vera samples, the following determinations were achieved: determination of the total phenolic content by the Folin-Ciocâlteu spectrophotometric method $(\lambda=750 \mathrm{~nm})$, determination of total flavonoid content by spectrophotometric method $(\lambda=500 \mathrm{~nm})$, determination of antioxidant capacity by DPPH method (Williams et al., 1995), determination of vitamin C by titrimetric method (Deac et al., 2014). Results of the total phenolic, flavonoid, antioxidant capacity and vitamin C content from the Aloe veragel, are presented in Table 1.

Table 1. Aloe vera gel characterization

\begin{tabular}{|c|c|c|c|c|}
\hline \multirow{2}{*}{ Aloe vera $\mathrm{gel}$} & $\begin{array}{c}\text { TPC } \\
(\mathrm{mg} \mathrm{GAE} / 100 \mathrm{~g})\end{array}$ & $\begin{array}{c}\text { Flavonoids } \\
(\mathrm{mg} \mathrm{QE} / 100 \mathrm{~g})\end{array}$ & $\begin{array}{c}\text { Antioxidant } \\
\text { activity }(\%)\end{array}$ & $\begin{array}{c}\text { Vitamin C } \\
\mathrm{mg} / 100 \mathrm{~g}\end{array}$ \\
\cline { 2 - 5 } & 20.68 & 0.248 & 3.81 & 7.04 \\
\hline
\end{tabular}

Determination of antimicrobial activity of essential oils and Aloe vera extract (minimum inhibitory concentration and minimum bactericidal concentration).

The concentration that resulted in complete inhibition of the bacteria (MIC) was the concentration corresponding to the culture wells where the blue colour did not turn pink. Two repetitions for each sample were performed. The minimum bactericidal concentration (MBC) was achieved by inoculating on Mueller Hinton agar from the last three culture wells where bacterial growth was completely inhibited. The results obtained can be found in Table 2 .

In our trials, the antimicrobial activity of thyme essential oil against Staphylococcus aureus ATCC 25923, Salmonella enteritidis ATCC 13076 and Escherichia coli ATCC 25922 was found to be lower than the antimicrobial activity of oregano essential oil. Based on these results, it was found that oregano essential oil had a higher antimicrobial activity than thyme essential oil (Olmedo et al., 2013; Carvalho et al., 2015) 
Table 2 . The susceptibility profile of bacteria $\left(1.5 \times 10^{8} \mathrm{CFU} / \mathrm{ml}\right)$ to thyme and oregano essential oils $(\mu \mathrm{l} / \mathrm{ml})$

\begin{tabular}{|c|c|c|c|c|}
\hline \multicolumn{2}{|c|}{ Samples } & $\begin{array}{c}\text { Staphylococcus aureus ATCC } \\
25923\end{array}$ & $\begin{array}{c}\text { Salmonella enteritidis } \\
\text { ATCC 13076 }\end{array}$ & $\begin{array}{c}\text { Escherichia coli } \\
\text { ATCC 25922 }\end{array}$ \\
\hline \multirow{2}{*}{$\begin{array}{c}\text { Thyme } \\
\text { essential oil }\end{array}$} & MIC & $0.27 \pm 0.00$ & $0.13 \pm 0.00$ & $0.06 \pm 0.00$ \\
\cline { 2 - 5 } & MBC & $0.27 \pm 0.00$ & $0.13 \pm 0.00$ & $0.06 \pm 0.00$ \\
\hline $\begin{array}{c}\text { Oregano } \\
\text { essential oil }\end{array}$ & MIC & $0.04 \pm 0.017$ & $0.01 \pm 0.00$ & $0.01 \pm 0.00$ \\
\cline { 2 - 5 } & MBC & $0.04 \pm 0.017$ & $0.01 \pm 0.00$ & $0.01 \pm 0.00$ \\
\hline \multicolumn{2}{|c|}{ Gentamicin } & 0.24 & $0.24 \pm 0.00$ & $0.05 \pm 0.00$ \\
\hline
\end{tabular}

The susceptibility of tested bacteria $\left(1.5 \times 10^{6} \mathrm{CFU} / \mathrm{ml}\right)$ to Aloe vera extract $(\mathrm{mg} / \mathrm{ml})$ is presented in Table 3. The minimum inhibitory concentration (MIC) and minimum bactericidal concentration (MBC) of the Aloe vera extract against microorganisms ranged from 37.79 to $56.58 \mathrm{mg} / \mathrm{ml}$. The study revealed that the Aloe vera extract has a greater medicinal potential against Staphylococcus aureus and Escherichia coli. Similarly, in another study, gram-positive test organisms were found to be more susceptible to the sterile Aloe vera extract (Shahzad et al., 2009).

Table 3. The susceptibility profile of bacteria $\left(1.5 \times 10^{6} \mathrm{CFU} / \mathrm{ml}\right)$ to Aloe vera extract $(\mathrm{mg} / \mathrm{ml})$

\begin{tabular}{|c|c|c|c|}
\hline $\begin{array}{c}\text { Aloe vrea } \\
\text { extract }\end{array}$ & $\begin{array}{c}\text { Staphylococcus aureus } \\
\text { ATCC } 25923\end{array}$ & $\begin{array}{c}\text { Salmonella enteritidis } \\
\text { ATCC 13076 }\end{array}$ & $\begin{array}{c}\text { Escherichia coli } \\
\text { ATCC 25922 }\end{array}$ \\
\hline MIC & $37.79 \pm 0.017$ & $56.58 \pm 0.00$ & $37.79 \pm 0.017$ \\
\hline MBC & $37.79 \pm 0.017$ & $56.58 \pm 0.00$ & $37.79 \pm 0.017$ \\
\hline $\begin{array}{c}\text { Gentamicin } \\
(\mu \mathrm{g} / \mathrm{ml})\end{array}$ & $0.05 \pm 0.00$ & $0.05 \pm 0.00$ & $0.05 \pm 0.00$ \\
\hline
\end{tabular}

Determination of pathogenic microorganisms (coagulase-positive staphylococci and Escherichia coli) during storage highlighting the influence of essential oils and Aloe vera microcapsules on their evolution.

Table 4 presents the results of the microbiological determinations of the spreadable goat cheeses.

Table 4. Microbiological quality of the spreadable goat cheese assortments supplemented with Aloe vera microcapsules and essential oils

\begin{tabular}{|c|c|c|}
\hline Samples & Staphylococcus aureus & Escherichia coli \\
\hline P1O1 & Absent & Absent \\
\hline P2O2 & Absent & Absent \\
\hline P1C1 & Absent & Absent \\
\hline P2C2 & Absent & Absent \\
\hline Control sample & Absent & Absent \\
\hline
\end{tabular}

P1C1-7\% Aloe vera microcapsules and 0.0072\% thyme essential oil, P2C2-3\% Aloe vera microcapsules and 0.018\% thyme essential oil, P1O1-7\% Aloe vera microcapsules and 0.0072\% oregano essential oil, P2O2-3\% Aloe vera microcapsules and $0.018 \%$ oregano essential oil

\section{Physicochemical characteristics}

In this work the physicochemical and the sensory properties of all cheese samples were analysed. Cheese composition is shown in Table 5.

The fat and protein content found in the present study is similar to those reported by other authors for this variety of cheese (Frau et al., 2014). No significant differences were found in all treatments in regards to moisture, total protein, salt, and fat content of the cheese samples during storage. The addition of thyme and oregano essential oils in cheese did not seem to affect those parameters after spreadable cheese manufacturing and during storage (Table 5). 
The moisture and fat in dry matter content of all cheeses (control and Aloe vera/ essential oils) have been found to meet the mentioned standards ( $\leq 75 \%$ moisture and $\geq 40 \%$ FDM content) for fresh spreadable cheese (Aktypis et al., 2018). The results were similar to those found in commercial goat cheeses (Gambaro et al., 2017), in French goat milk cheeses (Raynal-Ljutovac et al., 2011) and those found by Vieitez et al. (2016). Regarding the salt and total protein content no, significant differences were found among the examined cheeses. The protein content was found to be, almost, constant during their storage and ranged from 10.08 to $10.84 \%$ (Table 5).

Table 5. Physicochemical characteristics of spreadable goat cheeses

\begin{tabular}{|c|c|c|c|c|c|c|c|}
\hline $\begin{array}{c}\text { Sample } \\
\text { Parameter }\end{array}$ & $\begin{array}{l}\text { Fat } \\
(\%)\end{array}$ & $\begin{array}{c}\text { Protein } \\
(\%)\end{array}$ & $\begin{array}{c}\text { Moisture } \\
(\%)\end{array}$ & $\begin{array}{l}\text { Total dry } \\
\text { matter }(\%)\end{array}$ & $\begin{array}{l}\text { Fat in dry } \\
\text { matter }(\%)\end{array}$ & $\begin{array}{l}\text { Salt } \\
(\%)\end{array}$ & $\begin{array}{c}\text { Acidity } \\
\left({ }^{\circ} \mathrm{T}\right)\end{array}$ \\
\hline $\begin{array}{l}\text { Control } \\
\text { sample }\end{array}$ & $19.68 \pm 0.042^{b}$ & $10.84 \pm 0.028^{a}$ & $68.20 \pm 0.325^{c}$ & $31.80 \pm 0.325^{a}$ & $61.90 \pm 0.481^{b c}$ & $0.411 \pm 0.031^{\mathrm{c}}$ & $150 \pm 5.657^{\mathrm{a}}$ \\
\hline P1C1 & $19.07 \pm 0.156^{b c}$ & $10.08 \pm 0.057^{b}$ & $70.77 \pm 0.580^{a}$ & $29.23 \pm 0.580^{c}$ & $65.26 \pm 1.824^{\mathrm{ab}}$ & $0.741 \pm 0.017^{\mathrm{a}}$ & $158 \pm 5.657^{\mathrm{a}}$ \\
\hline P2C2 & $20.92 \pm 0.184^{a}$ & $10.40 \pm 0.042^{b}$ & $69.52 \pm 0.057^{c}$ & $30.48 \pm 0.057^{b}$ & $68.63 \pm 0.735^{\mathrm{a}}$ & $0.684 \pm 0.016^{\mathrm{ab}}$ & $155 \pm 1.414^{\mathrm{a}}$ \\
\hline $\mathrm{P} 1 \mathrm{O} 1$ & $17.56 \pm 0.170^{\mathrm{d}}$ & $10.29 \pm 0.141^{b}$ & $70.16 \pm 0.113^{\mathrm{ab}}$ & $29.84 \pm 0.113^{b c}$ & $58.85 \pm 0.346^{c}$ & $0.694 \pm 0.007^{\mathrm{ab}}$ & $157 \pm 1.414^{\mathrm{a}}$ \\
\hline $\mathrm{P} 2 \mathrm{O} 2$ & $18.61 \pm 0.212^{c}$ & $10.40 \pm 0.099^{\mathrm{b}}$ & $69.64 \pm 0.042^{\mathrm{ab}}$ & $30.06 \pm 0.042^{\mathrm{bc}}$ & $61.30 \pm 0.785^{\mathrm{c}}$ & $0.635 \pm 0.004^{\mathrm{b}}$ & $152 \pm 2.828^{a}$ \\
\hline$p$ & $0.000^{* * *}$ & $0.002^{* *}$ & $0.003^{* *}$ & $0.003^{* *}$ & $0.001^{* *}$ & $0.000^{* * *}$ & $0.332^{\mathrm{NS}}$ \\
\hline
\end{tabular}

Different letters in the same column indicate statistically significant differences at $\mathrm{p}<0.05$ (Tukey's test). Significance: $p \geq 0.05^{\mathrm{NS}}$, not significant; $p<0.01^{* *}$, very significant; $p<0.001^{* * *}$, extremely significant.

\section{Sensory evaluation of cream cheese}

Ratings for flavour and textural attributes of spreadable goat cheeses are presented in Figure 2 and Figure 3 , respectively.

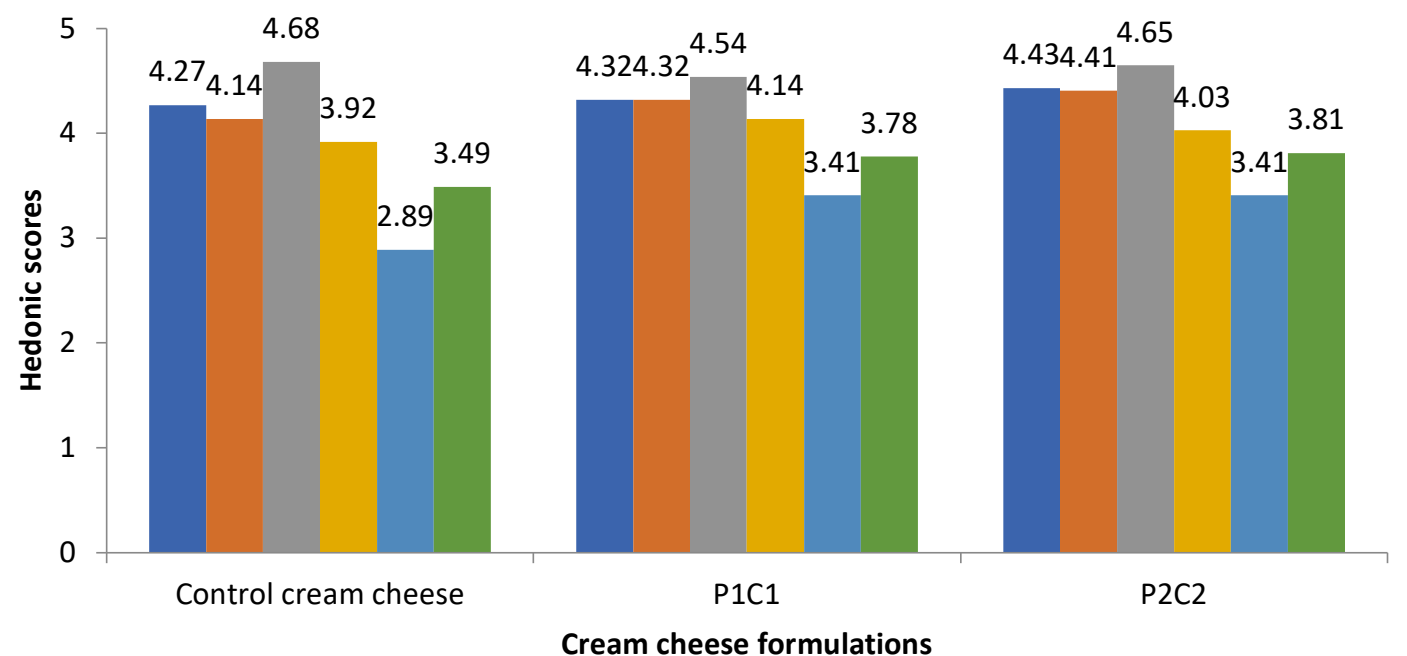

- Appearance Consistency Colour Smell Taste $\quad$ Overall appreciation

Figure 2. Sensory characteristics of control and spreadable goat cheese with thyme essential oil and Aloe vera gel microcapsules 


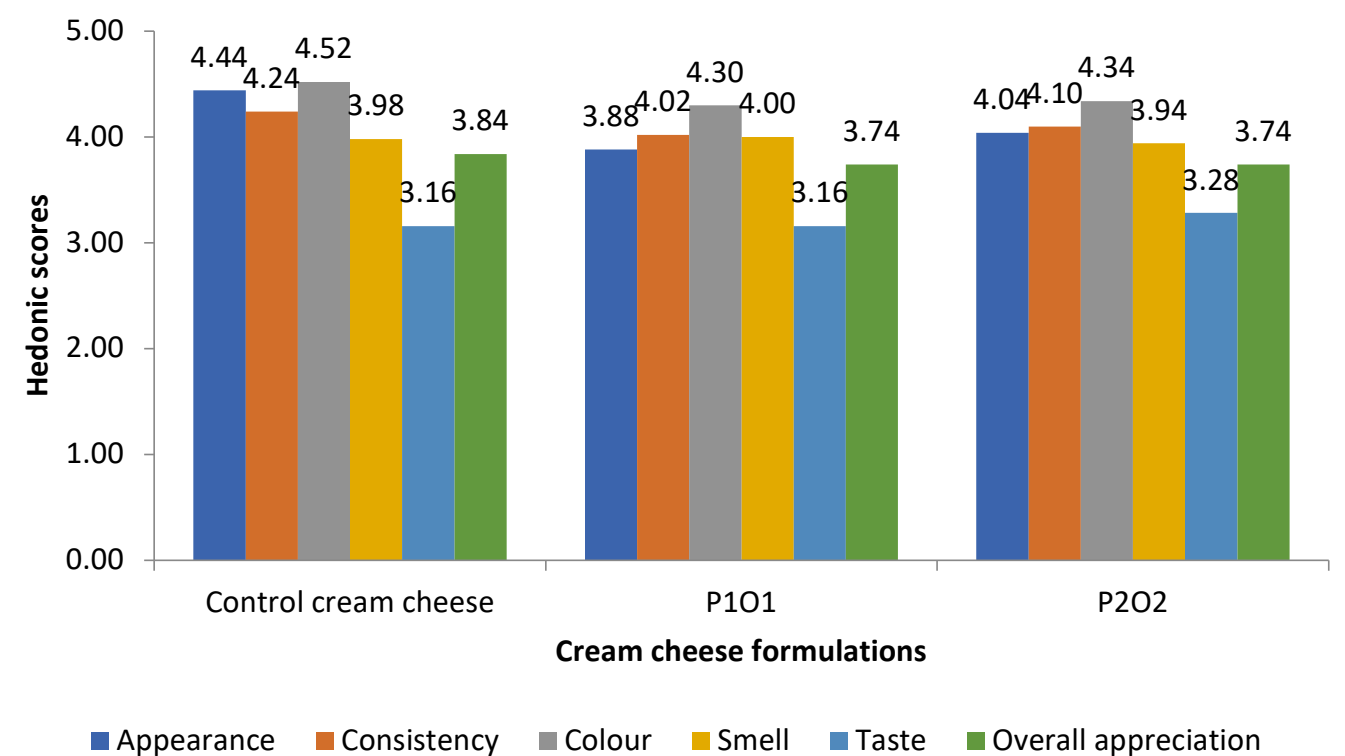

Figure 3. Sensory characteristics of control and spreadable goat cheese with oregano essential oil and Aloe vera gelmicrocapsules

As shown in Figures 2 and 3, the panellists found the differences in appearance, consistency, and colour between control, $\mathrm{P} 1 \mathrm{C} 1$ and $\mathrm{P} 2 \mathrm{C} 2$ cheese samples.

However, the thyme/oregano spreadable goat cheese analogue with higher content of Aloe vera gel microcapsules addition was poorer in consistency and appearance as reflected by their lower score. The lower score in appearance and consistency of P1C1 and P1O1 was likely due to the denser microstructure which made the sample too hard. In addition, the lower score in taste and consistency of P1C1 and P1O1 samples might be due to the too soft feeling of the samples resulting from the high moisture level of the product (Liu et al., 2008).

In terms of consumer preference, the cream cheese sample with $3 \%$ Aloe vera gel microcapsules and $0.018 \%$ thyme essential oil was the most appreciated (P2C2). Regarding cheese samples with the addition of oregano essential oil and Aloe vera gel microcapsules, the sample with 3\% Aloe vera and $0.018 \%$ oregano essential oil was the most appreciated (P2O2) as appearance, consistency, and taste, compared to the sample with more microcapsules and less oregano oil.

The cheese sample with $7 \%$ microcapsules and $0.0072 \%$ oregano essential oil, was more appreciated in terms of smell. The lower score in taste and consistency of the P1O1 sample was likely due to the denser microstructure which made the sample too hard (Jeon et al., 2012).

\section{Conclusions}

In this work, the influence of Aloe vera gel microcapsules and essential oils addition on physicochemical, microbiological, and sensory properties of spreadable goat's cheese was investigated. The results highlighted that the best results, from a nutritional point of view, were obtained for the cheese samples with lower Aloe vera and higher thyme essential oil content. In addition, the spreadable goat's cheese with oregano essential oil exhibited a more intensive antimicrobial activity against Salmonella enteritidis and Escherichia coli. The sensory analysis showed that the lesser Aloe vera gel microcapsules fortification of $3 \%$ resulted to an acceptable spreadable cheese, which kept its traditional taste and aroma. Based on the above, Aloe Vera and thyme essential oil could be successfully used as natural flavours in spreadable cheese manufacture providing also antimicrobial 
and functional properties. Enrichment of dairy products with polyphenols from Aloe vera plants can positively influence their oxidative stability and it may contribute to a decline in the incidence of degenerative human diseases.

\section{Authors' Contributions}

All authors contributed to the review and the editing of the article. MAJ wrote the manuscript and supervised in final reviewer the manuscript.

AMR, CRP and LCS participated in the experiment of this study. VAB performed PCR analysis. CAS supervised data analysis. DT and DM designed and conducted the research. AB in reviewer of the manuscript. All authors read and approved the final manuscript.

\section{Acknowledgements}

This work was supported by a grant of Ministry of Research and Innovation, CNCS - UEFISCDI, project number $180 \mathrm{CI} / 2018$.

\section{Conflict of Interests}

The authors declare that there are no conflicts of interest related to this article.

\section{References}

Aktypis A, Christodoulou ED, Manolopoulou E, Georgala A, Daferera D, Polysiou M (2018). Fresh ovine cheese supplemented with saffron (Crocus sativus L.): Impact on microbiological, physicochemical, antioxidant, color and sensory characteristics during storage. Small Ruminant Research 167:32-38. https://doi.org/10.1016/j.smallrumres.2018.07.016

Albenzio M, Santillo A (2011). Biochemical characteristics of ewe and goat milk: Effect on the quality of dairy products. Small Ruminant Research 101:33-40. https://doi.org/10.1016/j.smallrumres.2011.09.023

Amatiste S, Sagrafoli D, Giacinti G, Rosa G, Carfora V, Marri N, Rosati R (2014). Antimicrobial activity of essential oils against staphylococcus aureus in fresh sheep cheese. Italian Journal of Food Safety 3(3):148-150. https://doi.org/10.4081/ijfs.2014.1696

Boudreau MD, Beland FA (2006). An evaluation of the biological and toxicological properties of Aloe barbadensis (Miller), Aloe vera. Journal of Environmental Science and Health Part C 24:103-154. https://doi.org/10.1080/10590500600614303

Brčina T, Vilušić M, Moranjak M (2017). Sensory properties of dairy products based on fresh cheese and fruit. Technologica Acta10(2):1-8.

Burt SA, Reinders RD (2003). Antibacterial activity of selected plant essential oils against Escherichia coli O157-H7. Letters Applied Microbiology 36:162-167 https://doi.org/10.1046/j.1472-765X.2003.01285.x

Carvalho RJ, de Souza GT, Honorio VG, de Sousa JP, da Conceiçao ML, Maganani M, de Souza EL, (2015). Comparative inhibitory effects of Thymus vulgaris L. essential oil against Staphylococcus aureus, Listeria monocytogenes and mesophilic starter co-culture in cheese-mimicking models. Food Microbiology 52:59-65. https://doi.org/10.1016/j.fm.2015.07.003

Cock LS, Castillo VV (2013). Probiotic encapsulation. African Journal of Microbiology Research 7(40):4743-4753. https://doi:10.5897/AJMR2013.5718 
Čvek D, Markov K, Frece J, Dragičević TL, Majica M, Delaš F (2010). Growth inhibition of Aspergillus ochraceus ZMPBF 318 and Penicillium expansum ZMPBF 565 by four essential oils. Arhiv za Higijenu Rada i Toksikologiju 61(2):191-196. https://doi.org/10.2478/10004-1254-61-2010-2009

Deac LM, Fărcaş A, Vodnar DC, Tofană M, Socaci SA (2014). Antioxidant and Antimicrobial Properties of the Fir Buds Syrup. Bulletin UASVM Food Science and Technology 71(1):77-78. http://dx.doi.org/10.15835/buasvmcnfst: 10123

Frau F, Font de Valdez G, Pece N (2014). Effect of pasteurization temperature, starter culture, and incubation temperature on the physicochemical properties, yield, rheology, and sensory characteristics of spreadable goat cheese. Journal of Food Processing Volume 2014:1-8. https://doi.org/10.1155/2014/705746

Gambaro A, Gonzalez V, Jimenez S, Arechavaleta A, Irigaray B, Callejas N, ... Vieitez I (2016). Chemical and sensory profiles of commercial goat cheeses. International Dairy Journal 69:1-8. http://dx.doi.org/10.1016/j.idairyj.2017.01.009

Hamedi H, Razavi-Rohani SM, Gandomi H (2014). Combination effect of essential oils of some herbs with monolaurin on growth and survival of Listeria monocytogenes in culture media and cheese. Journal of Food Processing and Preservation 38(1):304-310. https://doi.org/10.1111/j.1745-4549.2012.00778.x

Harlev E, Nevo E, Lansky E, Ofir R, Bishayee A (2012). Anticancer potential of aloes: antioxidant, antiproliferative, and immunostimulatory attributes. Planta Medica 78:843-852. http://doi.org/10.1055/s-0031-1298453

Hassan FAM, Hayam MA, Mona AM, Abd El G, Ali KE (2014). Goats dairy products as a potentially functional food. Life Science Journal 11(9s):648-657.

Jeon SS, Lee SJ, Ganesan P, Kwak HS (2011). Comparative study of flavor, texture, and sensory in cream cheese and cholesterol-removed cream cheese. Food Science and Biotechnology 21(1):159-165. https://doi.org/10.1007/s10068-012-0020-6

Jeong EJ, Lee NK, Oh J, Jang SE, Lee JS, Bae IH, Jeong YS (2014). Inhibitory effect of cinnamon essential oils on selected cheese-contaminating fungi (Penicillium spp.) during the cheese-ripening process. Food Science and Biotechnology 23(4):1193-1198. https://doi.org/10.1007/s10068-014-0163-8

Kazhal S, Samira B (2015). Antifungal effect of Aloe Vera gel on Penicillium Citrinum in culture media and UF cheese. International Journal of Food Engineering 1(1):61-64. http://doi.org/10.18178/ijfe.1.1.61-64

Khorshidian N, Mojtaba Y, Elham K, Amir MM (2018). Potential application of essential oils as antimicrobial preservatives in cheese. Innovative Food Science and Emerging Technologies 45:62-72. http://dx.doi.org/10.1016/j.ifset.2017.09.020

Kotzekidou P, Giannakidis P, Boulamatsis A (2008). Antimicrobial activity of some plant extracts and essential oils against foodborne pathogens in vitro and on the fate of inoculated pathogens in chocolate. LWT - Food Science and Technology 41(1):119-127. https://doi.org/10.1016/j.lwt.2007.01.016

Liu H, Xu XM, Guo SD (2008). Comparison of full-fat and low-fat cheese analogues with or without pectin gel through microstructure, texture, rheology, thermal and sensory analysis. International Journal of Food Science and Technology 43:1581-1592. http://doi:10.1111/j.1365-2621.2007.01616.x

Marzanna H, Krzysztof D, Danuta G, Anna JG, Elżbieta G (2019). Aloe vera (L.) Webb.: Natural sources of antioxidants - a review. Plant Foods for Human Nutrition 74:255-265. http://doi.org/10.1007/s11130-019-00747-5

McKay D, Blumberg J (2006). A review of the bioactivity and potential health benefits of chamomile tea (Matricaria recutita L.). Phytotherapy Research 20:519-530. https://doi.org/10.1002/ptr.1900

National Committee for Clinical Laboratory Standards (1997). Methods for dilution antimicrobial susceptibility tests for bacteria that grow aerobically - fourth edition: approved standard, M7-A4. Villanova, Pennsylvania: National Committee for Clinical Laboratory Standards.

Olmedo RH, Nepote V, Grosso NR (2013). Preservation of sensory and chemical properties in flavoured cheese prepared with cream cheese base using oregano and rosemary essential oils. LWT - Food Science and Technology 53:409417. http://dx.doi.org/10.1016/j.lwt.2013.04.007

Raynal-Ljutovac K, Le Pape M, Gaborit P, Barrucand P (2011). French goat milk cheeses: An overview on their nutritional and sensorial characteristics and their impacts on consumers' acceptance. Small Ruminant Research 101:64-72. https://doi.org/10.1016/j.smallrumres.2011.09.026

de Oliveira ACL, Tabrez S, Shakil S, Khan MI, Asghar MN, Matias BD, ... de Carvalho Melo-Cavalcante AA (2018). Mutagenic, antioxidant and wound healing properties of Aloe vera. Journal of Ethnopharmacology 227:191197. http://doi.org/10.1016/j.jep.2018.08.034 
Sahu PK, Giri DD, Singh R, Pandey P, Gupta S, Shrivastava AK, ... Pandey KD (2013). Therapeutic and medicinal uses of Aloe vera: a review. Pharmacology \& Pharmacy 4:599-610. http://doi.org/10.4236/pp.2013.48086

Sakkas H, Papadopoulou P (2017). Antimicrobial activity of basil, oregano, and thyme essential oils. Journal of Microbiology and Biotechnology 27(3):429-438. https://doi.org/10.4014/jmb.1608.08024

Shahzad K, Ahmad R, Nawaz S, Saeed S, Iqbal Z (2009). Comparative antimicrobial activity of aloe vera gel on microorganisms of public health significance. Pharmacologyonline 1:416-423.

Vieitez I, Callejas N, Saibene M, Cabrera L, Irigaray B, Grompone MA (2016). Fatty acids and triglycerides composition in Uruguayan cow, sheep and goat cheeses. Journal of Food Science and Engineering 3:379-387.

Williams BME, Berset CC (1995). Use of a free radical method to evaluate antioxidant activity. LWT - Food Science and Technology 28(1):25-30. https://doi.org/10.1016/S0023-6438(95)80008-5

Yahyazadeh M, Omidbaigi R, Zare R, Taheri H (2008). Effect of some essential oils on mycelial growth of Penicillium digitatum Sacc. World Journal of Microbiology and Biotechnology 24(8):1445-1450. https://doi.org/10.1007/s11274-007-9636-8

Yousefi AM, Khorshidian N, Mortazavian AM, Hosseini H (2017). A review on the impact of herbal extracts and essential oils on viability of probiotics in fermented milks. Current Nutrition \& Food Science 13(1):6-15. https://doi.org/ 10.2174/1573401312666161017143415

*** Regulation (EC) no 1334/2008 of the european parliament and of the council on flavourings and certain food ingredients with flavouring properties for use in and on foods.

*** SR ISO 3433:2009. Brânză. Determinarea conținutului de grăsime. Metoda Van Gulik

*** SR EN ISO 8968-1:2014. Lapte şi produse din lapte. Determinarea conținutului de azot. Partea 1: Metoda Kjeldahl şi calculul conținutului de proteină brută

*** SR EN ISO 5534:2004. Brânzeturi şi brânzeturi procesate. Determinarea conținutului total de substanță uscată (Metoda de referință)

***SR EN ISO 5943:2007. Brânză şi produse din brânză procesată. Determinarea conţinutului de cloruri. Metoda prin titrare potențiometrică

*** SR ISO 1740:2008. Produse din grăsime din lapte şi unt. Determinarea acidității grăsimii (Metodă de referință)

*** SR ISO 16649-2: 2007 Microbiology of food and feed - Horizontal method for the enumeration of positive Escherichia coli beta-glucuronidase.

*** SR ISO 6881-1: 1999 Microbiology of food and animal feeding stuffs - Horizontal method for the enumeration of coagulase-positive staphylococci (Staphylococcus aureus and other species)
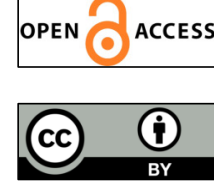

The journal offers free, immediate, and unrestricted access to peer-reviewed research and scholarly work. Users are allowed to read, download, copy, distribute, print, search, or link to the full texts of the articles, or use them for any other lawful purpose, without asking prior permission from the publisher or the author.

License - Articles published in Notulae Botanicae Horti Agrobotanici Cluj-Napoca are Open-Access, distributed under the terms and conditions of the Creative Commons Attribution (CC BY 4.0) License. (c) Articles by the authors; UASVM, Cluj-Napoca, Romania. The journal allows the author(s) to hold the copyright/to retain publishing rights without restriction. 